ARTIGO

\title{
THE FORMATION OF COLLECTIVE SUBJECTS' SMALL SOCIAL GROUPS IN THE INFORMATION AGE (PROBLEM OF IDENTITY)
}

\author{
FORMACIÓN DE SUJETOS COLECTIVOS DE PEQUEÑOS GRUPOS SOCIALES EN
}

LA EPOCA DE INFORMACIÓN (PROBLEMA DE IDENTIDAD)

\author{
FORMAÇÃO DE ASSUNTOS COLETIVOS DE PEQUENOS GRUPOS SOCIAIS NA \\ ÉPOCA DA INFORMAÇÃO (PROBLEMA DE IDENTIDADE)
}

\author{
Vadym I. Palahuta \\ National Metallurgical Academy of Ukraine - Ukraine
}

Stanislav S. Beskaravainyi

National Metallurgical Academy of Ukraine - Ukraine

\begin{abstract}
Resumo: O objetivo do artigo: estudar o impacto da tecnologia de inteligência artificial (IA) na sociedade, o que leva à formação de grupos sociais fundamentalmente novos. A maior diversidade e liberdade de desenvolvimento será alocada para pequenos grupos sociais que interagem diretamente com a IA. O modelo do novo grupo social deve responder às seguintes perguntas: que oportunidades a IA oferece? Qual o papel da IA em um pequeno grupo social? Como as pessoas se identificam com um grupo semelhante? Utilizou-se a descrição da estrutura de pequenos grupos sociais, determinou-se o papel multissubjetivo do organizador e intermediário da IA. O conceito de "comunidade situacional" foi usado para revelar a estrutura de equilíbrio de tais grupos, onde a identidade individual ou de grupo domina. Em várias situações, a IA poderá substituir uma pessoa que deixou o grupo como líder, ou garantir a estrita observância das configurações inalteradas para o grupo, ou desempenhar o papel de um organizador coletivo-sombra, que, a fim de preservar a integridade do grupo, pode transformar suas metas e objetivos. Graças à IA, pequenos grupos sociais terão acesso às ferramentas para organizar atividades que anteriormente tinham apenas estruturas sociais maiores. Um aumento na subjetividade pode levar a transformações significativas e uma mudança no papel desses grupos sociais. Uma ameaça foi identificada: o indivíduo pode não ser capaz de abandonar independentemente sua identificação comportamental-cognitiva e emocional com o grupo.
\end{abstract}

Palavras chave: Comunidades situacionais, inteligência artificial, sujeito coletivo. Abstract: The article takes a new look at the impact of artificial intelligence (AI) technology on society,
which leads to the formation of fundamentally new social groups. The greatest diversity and freedom of
development will be allocated to small social groups that directly interact with AI. The model of the
new social group should answer the following questions: what opportunities does AI offer? What role
can AI play in a small social group? How will people identify with a similar group? The description of
the structure of small social groups was used, the multisubject role of the organizer and intermediary of 
the AI was determined. The concept of «situational community» was used to reveal the equilibrium structure of such groups, where either individual or group identity dominates. In some situations, the AI will be able to replace the person who has left the group as a leader, or to ensure strict observance of the settings that are unchanged for the group, or to play the role of an implicit collective organizer, which, in order to preserve the integrity of the group, transforms its goals and objectives. Small social groups, thanks to AI, will gain access to professional skills and tools for organizing labor that previously had larger social structures. An increase in subjectivity can lead to significant transformations and a change in the role of these social groups. A threat has been identified: the individual may not be able to independently abandon his behavioral-cognitive and emotional identification with the group.

Keywords: Artificial intelligence, collective subject, situational communities.

Resumen: El propósito del artículo: estudiar el impacto de la tecnología de inteligencia artificial (IA) en la sociedad, lo que lleva a la formación de grupos sociales fundamentalmente nuevos. La mayor diversidad y libertad de desarrollo se asignará a pequeños grupos sociales que interactúan directamente con la IA. El modelo del nuevo grupo social debería responder las siguientes preguntas: ¿qué oportunidades ofrece la IA? ¿Qué papel puede desempeñar la IA en un pequeño grupo social? ¿Cómo se identificarán las personas con un grupo similar? Se utilizó la descripción de la estructura de pequeños grupos sociales, se determinó el rol multisubjetivo del organizador y el intermediario de la IA. El concepto de "comunidad situacional" se utilizó para revelar la estructura de equilibrio de dichos grupos, donde domina la identidad individual o grupal. En una serie de situaciones, AI podrá reemplazar a una persona que ha dejado el grupo como líder, o para garantizar el estricto cumplimiento de las configuraciones que no cambian para el grupo, o para desempeñar el papel de un organizador colectivo en la sombra, que, para preservar la integridad del grupo, puede transformar sus metas y objetivos. Gracias a la IA, pequeños grupos sociales obtendrán acceso a las herramientas para organizar actividades que anteriormente solo tenían estructuras sociales más grandes. Un aumento en la subjetividad puede conducir a transformaciones significativas y un cambio en el papel de estos grupos sociales. Se ha identificado una amenaza: el individuo puede no ser capaz de abandonar independientemente su identificación conductual-cognitiva y emocional con el grupo.

Palabras clave: Inteligencia artificial, sujeto colectivo, comunidades situacionales.

\section{INTRODUCTION}

Modern priority research of artificial intelligence (AI) is focused on its improving (creating of so-called «strong AI»), and also on its utilitarian, applied us in industry and the sphere of consumption. Both the political and social aspects of the widespread use of AI are considered, but less attention is paid to the sum of scientific publications.

Thinkers are fully aware that future changes will affect a person: the famous British social theorist J. Urry predicts:

That by the middle of this century an exceptional, explosive development of intelligence is possible when computer`s intelligence will surpass the combined power of human intelligence. <> The nature of man as a biological species will undergo serious changes. (URRY, 2018, p. 215-216). 
Changes in society are predicted as dramatic and irreversible.

The forms of influence of AI on society are also extremely diverse, and the transformation of individual specialties, their application in public administration, business, trade, medicine, etc., are mainly evaluated. Large social groups are initially selected as reference objects for evaluating these processes, since the transformation of the behavior of a large number of people affects society as much as possible.

On this background, a small social group remains in the shadow of research. The behavior of «human-machine teams» is being actively investigated (DEMIR, COOKE, 2018), which organized for the execution of any technological operations or the applied complex of tasks. Researchers are trying to gauge workers' confidence in robots or programs in humanmachine teams (ACADEMIC PRESS, 2019). But it is precisely formalized labor relations that are being investigated. In the typical review of last year's work «Artificial Intelligence in Society» (OECD PUBLISHING, 2019) - families, family businesses, small clubs, partnerships and communities received minimal attention.

But the cells of society are precisely small social groups. AI, as a carrier of various algorithms, opens up the possibility for these groups of new self-organization, training in new skills and new forms of information processing, which are now inaccessible outside of any professional environment. The state of large social groups is constantly analyzed, and in such control states have extensive experience - the spread of any professional skills there will not lead to disastrous consequences. For example, the massive proliferation of firearms in some countries does not in itself lead to civil wars. Individual use of AI is limited by human working capacity. If the capabilities of $\mathrm{AI}$ in tandem with a person will significantly exceed the capabilities of a person, then it will be a question of controlling and observing the AI itself, and not its nominal owner. Against this background, small social groups (3-15 people), on the one hand, can have impacts that are significant for the whole society (starting from small groups managing destructive cults and ending with associations of leading specialists in the responsible design bureau (DB), or power-political groupings). On the other hand, small social groups have unique specifics and cannot be controlled due to their large number.

Under these conditions, the critical factor is the problem of human identity in a small social group, the qualitative difference of which will be collaboration with AI. How much can he put his values and goals above individual or social values? How much will reasoning methods of an individual and the form of his experiences be subordinated to the norms and patterns of the group? How much can his self-identification within one group lead to exclusion 
from other social groups - and his actual marginalization? And in what critical circumstances can an individual separate himself from such a group?

The answers to these questions must be sought before the widespread dissemination of AI allows many families move to autonomy, which borders on self-isolation, and to individual groups with antisocial behavior - abruptly increase their effectiveness.

\section{GOAL}

to draw up a preliminary structure of the model, which is able to describe:

a) forms of AI participation in self-support of a small social group,

b) forms of identification of individual with a similar group,

c) boundary conditions for identifying an individual and a small social group.

\section{BASIC MATERIAL}

At the moment, the idea of the «Turing test» as the ideal requirements for computer intelligence is inadequate. Machines actually passed the Turing test, and can deal with any code systems better than people (MARCUS, 2014). Indirect evidence of this can be called computer victory over man in almost all games and improved electronic translation. Of course, there is a barrier to abstracting-concretization (computers have not yet formulated new concepts based on observed phenomena), and also physical barrier (modern robots still control bodies much worse than humans). Actual tasks of mastering the plastic of a 4-year-old child are relevant (BROOKS, 2019), although non-verbal interaction with a person - reading words on the lips or various gestures - progressing rapidly (MAVRIDIS, 2015). That is, we can talk about the formation of new forms of interaction between man and machine, in which a computer will work more effectively with people with sign systems. Moreover, the famous British astrophysicist S. Hawking predicted that «the world is on the verge of a new industrial revolution of robots» and at the same time asked a burning question - «can robots be given legal rights as electronic personalities along with the legal definition of corporate personalities?»(HAWKING, 2019, p. 224).

With a similar statement of the problem, it is necessary to change the approach to understanding the subjectivity itself. In other words, human subjectivity can no longer be identified only with the individual as such. In fact, we have a multi-level structure of subjectivity (from the individual "I" to corporate, gender, political, ethnic, regional and other types of subjectivity), which determines the life guidelines, behavior and activities of a person 
as a whole. The structure of subjectivity is largely based on sign systems, but not only verbal ones. In this case, we are already talking about polysubjectivity, where the moment of event uniqueness is important.

The construction of the sociality of a multiple subject becomes fundamentally different: polysubjectivity (simplifying - different positioning by the subject of himself in different circumstances, which are determined by the position or place in the emerging social structure), which suggests dynamic forms of interaction and cooperation. By their nature, they are very dynamic and changeable, they are compositions of social ties between different subjects, not reducible to a common definition and unfolding in a spatio-temporal perspective. But what is most important here is that the social is constructed only through the connection of not only different, but also a kind of «expanded» subjects, and therefore, the distinction is not reducible in principle. Moreover, «expanded» subjectivity is constantly in the process of social reconstruction, which fully expresses the concept of «singularity».

If we turn to the philosophical and ontological meaning of the concept of «singularity» and abstract from its various analogues in mathematics, biology, astrophysics and other sciences, then its most developed interpretation is J.L. Nancy. The French philosopher emphasized that «ontology as a «sociality» or as a «socialization», more primordial than any society, than any «individuality» and than any «essence of being», in this ontology, being is together» (NANCY, 2004, p. 68). It is important to note here the aspect that «being together» is not reduced to the classical understanding of «general being», where the particular is reduced to the general. The fundamental difference between these provisions is the singularity (convergence to unique) of the final existence of the subject, which is characteristic only of the final individual existence. Therefore, «being-together» is realized in this place «between» the general and the individual, the identical and the different. At the same time, singularity is understood both as singleness and uniqueness, and as the most important condition for the reproduction of sociality: «There is no togetherness, there is no general being, but there is only being together. Every ontology, now being the logic of being in itself as being to itself, also reduces to the in-place of these «to-ones» (NANCY, 2009, p. 150-151).

It should be noted that in the French philosopher, sociality is constituted only in acts of distinctions, which presupposes exclusively «being-to-another», but only to some specific imaginary Other, which somewhat narrows the conceptual significance of the singularity as a polysubjectivity. On the contrary, its broad interpretation as the multiplicity of others, which give rise to the equally differentiated subjects as such. This implicitly implies diverse forms of activity in the interaction of these equally different entities. Ultimately, polysubjectivity is the 
result of a kind of deconstruction of traditional unity (individuality, collectivity) in favor of local compatibility in temporary or situational communities, when new forms of sociality are constructed each time.

The existence of situational communities (and communities where AI is present and are of this type) also involves the continuous construction of sociality in the form of an endless game of differences.

But how is the identity of the subject possible with a «floating» sociality? Only upon recognition of the right to autonomous existence within a certain, albeit temporarily existing social whole, where it coexists with other such identities. But then the natural question arises: is it possible for the coexistence of identities without universal norms and rules shared by all subjects included in a single whole? The coexistence of multiple identities of subjects without any universal norms and rules is only capable of constituting a type of heterogeneous sociality, which is an obvious paradox. According to T. Kerymov in his work, this paradox is insoluble, being a condition for the possibility of heterogeneous sociality. This position is illustrated by the following reasoning:

Paradox resolution allows the possibility for heterogeneous multiplicity ordering, the possibility of its representation. <> If society is possible as such, then only because society is deprived of the general (content) and private form of its representation. (KERYMOV, 2007, p. 27).

Based on a similar understanding of the social phenomenon, where a combination of these two factors - polysubjectivity and heterogeneous sociality constructs a situational community. It opens up the possibility of the existence of an individually-collective, humanmachine subjectivity, where the individual not only is in close personal cooperation with the computer, but understands that the team in which he takes an active part also makes decisions together with computers.

Thus, it is possible to determine the prerequisites of a new situational community:

- even if the formation of human-machine subjectivity is going on at all levels individual, the level of a small social group and society as a whole - it is extremely heterogeneous in its qualities. At the state level, there are practices and a tradition of self control and control of megamachines and technostructures, as well as no less real tradition of minimizing their impact on the social group. At the individual level, we face problems, which expressed in the concepts of transhumanism: the transformation of a person, an organism, its consciousness under the influence of cooperation with a machine. Such technologies are taken 
with great care, for them it is necessary to formulate moral and ethical requirements and restrictions;

- the impact at the level of a small group may be decisive for a given situational community:

a) local and, at the same time, unique;

b) it can bring a changed group new opportunities in self-realization, the acquisition of new professional skills, forms of participation in public life;

c) can close the feedback loop - when new changes in the group lead to ever greater pragmatic benefits, which require new changes and transformations, both from the small group and from the individuals themselves;

d) at the same time, a change in the human body is not necessary.

In what forms can a modern $\mathrm{AI}$, or $\mathrm{AI}$ in the near historical perspective, influence a small social group? The following aspects can be distinguished here:

- the creation and maintenance of communicative space, that is, ensuring the communicative unity of the group, creating its virtual unity in time and space. It is not only a matter of mobility of communication and the ability to exchange large amounts of information. It provides the function of a mediator, a secretary who can reduce the personal barrier of rejection - knowing the daily routine and tracking individuals in real time, choose the time and form of communication (avoid emotional conflict), remind of practical actions necessary to maintain the unity of the group, etc. For AI, it will be organic to use a wide range of virtual reality, which the computer can quickly change to the pragmatic and emotional needs of a group or individual individuals (when individuals can engage in dialogue, being in different communicative spaces);

- form of goal-setting: AI can develop a permanent goal for the joint activities of this group. The needs that are formulated by individuals are formalized by the goals that they need to achieve in the process of achieving these desires. And the goals are developed on the basis of the capabilities of the group members and the actual ways of their use, the conjuncture of which is assessed precisely by AI. Search for profitable ways of investing capital, promising professions, training courses, etc. (SOHOVA, REDKO 2019). Nowadays, small social groups are largely guided by public indicators that are formulated by government agencies or the media. But the analytical capabilities of AI will allow to rely on forecasts of higher quality. AI can create long-term forecasts of the existence of a social group, and is guaranteed to act in its interests; 
- the organizing beginning of AI. So far, the neural network cannot take on the role of leader. An exception is in stable groups in which the activity of their leader is terminated, and the rest cannot fulfill his functions. But situationally, he can play the role of a leader now. For example, a translator or an expert has power over people, it is a neural network, taking into account hundreds of factors at the same time, that can analytically confirm the similarity of situations in the economy, trade relations or politics. But the external situation favorable for the social group, which is confirmed by the «weak AI», will require the fulfillment of certain roles by its participants, which, in turn, will be determined by the same neural network. So, the power of an expert program, that modern society is ready to accept, becomes the power of a manager program, that is, $\mathrm{AI}$ is an organizing form;

- normalizing and controlling role. AI involves the separation of personal roles in a group. AI is an ideal calculator of the labor and productivity of each member of the group. He can draw up their psychological portraits on the basis of biography and those personal data that individuals do not want to give to outsiders persons;

- the formation of a group culture, the practice of verbal and non-verbal communication. For example, AI can use euphemisms that were used at least once in a group, noting their binding to the most vivid emotional moments. So, intragroup jargon, the language of facial expressions and gestures, a set of significant images are developed relatively quickly. AI can be an almost ideal censor for the flow of external information;

- the production of intragroup emotional connections through AI. People will start to become attached to the habitat, to their familiar working environment, which will create AI. Already now, two problems can be distinguished that are most relevant for the social role of AI in the context of emotions: this is the problem of physicality and the fullness of the spectrum of analytical procedures in thinking. Each of them for its disclosure requires the individual work. There can only be seen that even in the absence of a well-controlled android robot, a small social group can act as a referent for AI in respect of: a) familiar motility, giving samples of facial expressions, gestures and plastics in general; b) to be a supplier of abstractions, new conceptual models. AI, deprived of android body, will be able to represent itself with the help of «Internet of things», controlling the environment of small social group, and this environment will serve as an ersatz of its physicality, a kind of sensory;

- coordinating role. AI will inevitably be used to communicate with other AIs, especially of a different structural level (for example, state structures). The simplest example is that a group AI acts as the primary lawyer, the primary legal representative on deals on behalf of the group, draws up a tax return for group members, evaluates certain bills in terms of group 
interests, etc. So, AI becomes an instrument of the collective subjectivization of a social group in relation to external factors, ensuring its autonomy, constant self-care constant care of itself, its strategy. The embryos of such human-machine interaction are already appearing themselves now in everyday moments. So, a car computer automatically pays a parking fee, negotiating with a computer in the parking lot, and for the amount paid, the driver is indicated a place to stop or place.

Similarly, group AI will be the main tool for evaluating computer programs and devices used by individual group members. So, not every individual in the group creates a computer environment for himself as an imprint of his personality, but partially adapts to the environment organized by the AI for him.

- the valueological role of AI, expressed in assessing the health of group members and providing, if necessary, medical care. As a tool for prevention, dieting and maintaining sanitation, AI, even with a modern level of robotics, can be very effective. If we assume that using a medical robot, it will be possible to produce minimally invasive operations, then the concept of human physicality in the group will inevitably blur: the body, as something controlled by consciousness, and which is home to the psyche, will be partially controlled not only by the individual's consciousness, but also by the collective «mind» of a group only mediated by an individual.

As an intermediate result of our research: polysubjectivity is associated with a multiple cause (BASHLYAR, 1987), and AI becomes one of the factors affecting the functioning of heterogeneous social activity of small social groups. And due to its capabilities, AI can perform multiple roles (secretariat, psychologist, adviser, mediator), which are now available to groups with significant resources, or professional expert organizations. It will stabilize the activities of situational communities. Then, individuals will be able to move from temporary cooperation to permanent and developed forms of interaction. This circumstance is largely due to the fact that AI will be able to discover new objects of individuals' work and partially eliminate group contradictions. It is important to emphasize here that any personal identity in the context of a situational community is defined as a social identity, and can be subjected to constant deconstruction and reconstruction. «Orienting oneself to one's own standards», which R. van Dick speaks of (VAN DICK, 2006, p. 70), is almost impossible here, because the personal standards that determine personal identity are formed by the situational community. But at the same time, the individual always has a kind of personality core, which ensures the continuity of various identifications of the individual. At the same time, the main deterrent factor to using 
AI to stabilize a small social group will be its own vulnerability to hacker attacks and other external negative influences.

How will be constructed personality identity of the individual, and what forms of identification will dominate in such small social group? So, in the study of social identity of the individual is quite widespread classification, which offers three components: cognitive, affective, and behavioral. To these components of an individual's social identity, an evaluation component is added as an additive effect of the cognitive and affective dimension of identity (VAN DICK, 2006).

Cognitive: individuals in such group will soon realize the unity of their knowledge and skills: compilation of the content of answers and the gradual achievement of the unity of form will be produced thanks to the «mediation» of AI. The implementation of «we-concepts» is possible through an increasing number of personal factors than even in modern families. Just because a neural network can analyze large amounts of data in search of regularities and find new unifying personality factors in the history of group relationships. Where individuals can only guess about the inclinations and tastes of their neighbors, the AI will be able to discover these tastes by analyzing the content requested by the user - and present it to the other individuals in a favorable light to the unity of the group;

Affective: group-wide emotional experiences are still achieved through the combined actions of individuals. Thus, various rituals (church attendance, joint lunch, watching sports, films) require a unity of time and place from the group. But already social networks and electronic games have shown that the emotional involvement of the user is accessible without the unity of time and place, even without the unity of purpose: the phenomenon of public bloggers, different variations of the «glass houses» when the user reaches emotional involvement by viewing posts or playing at a convenience for himself time - in transport or at lunch. AI will further strengthen this phenomenon, using the variety and originality of the forms of information presentation, at the same time focusing attention on the most important.

A separate problem is always the emotional involvement of new members of the group, a gradual change in their taste preferences. Here, the AI, constantly watching the individual, can predict negative emotional states, preventing the negative development of relations in the group.

Behavioral: the general style of behavior and activity in general, for example, the coordination of facial expressions, gestures and pantomimics, the character and tone of utterance. Here AI allows a better distribution of the role of images that inevitably must be different in the group. The simplest tool - is creating an image to follow. If an individual sees 
himself in a mirror, his own image is slightly changed on the neighboring display, and he can easily change his facial expressions, gestures, posture, correct his clothes, etc., and then he will do so with a high probability (a separate issue is raising children using similar methods).

Here we can point out two universal mechanisms for achieving group identity:

Representation, vision by the subject of another person as an extension of himself, endowing him with his own traits, feelings, desires» and «the mechanism by which the subject puts himself in the place of another, leading to the assimilation of the personal meanings of the latter. (BAZAROV; KUZMINA, 2005, 30-45 p.).

The most important criterion for the stability of a group is the ability to overcome internal conflicts. Both purely pragmatic, so purely emotional, or overcoming contradictions and disagreements between a leader and a group, or subgroups.

AI trained using game theory can provide «cooperation without exploitation», that is, interact between members of a group exclusively for mutually beneficial actions (LERER; PEYSAKHOVICH, 2018). Then the group exists for some time, and if the pragmatic interests of its members begin to contradict each other, the periods of communication are reduced, and the group gradually begins to disintegrate. All emotional and behavioral signs of unity are not perceived by the members of the group as mandatory, as requiring the restructuring of their own personality. Now there are various cooperatives, interest communities such as philatelist clubs, chess lovers or reenactors. Self-identification is easily accepted, and just as easily lost.

A completely different picture arises when individuals included in a social group are obviously ready to study, improve themselves, seriously change their lifestyle, transform their attitudes and preferences.

Here the most important trilemma arises, which allows to determine the forms of identification of an individual in a small social group and indicates the boundary conditions for the identification of an individual and a small social group even before a detailed study of the modern pace of AI development. They were practically not used as characteristics of small social groups:

a) AI, as an assistant and one of the centers of polysubjectivity, can completely obey the leader of the group. It can be argued that this is the boundary condition for the identification of the individual and a small social group, because it opens up a wide field for controlling the consciousness of group members, which can lead to various forms of exploitation and misuse. The individual begins to exist subjectively in an artificially created reality, communicating with the «charismatic leader», which image is formed in his mind with the help of AI. A rollback to 
a certain kind of medieval religious worldview may occur when a person perceives the world holistically, organically, seeing in any bright event the will of higher forces leading a dialogue with him (STYOPIN; KUZNETSOVA, 1994). The identity of the individual and the small social group can be determined not by the utilitarian benefits, but literally - by the worldviews individual. He cannot think of his being outside the group. And the limits of influence on him are limited either by the leader's self-control, or by the interference of various state structures. The embodiment of such model can be not so much destructive cults as large families, where parents, entrusting the education to family AI, completely determine the way of life of children, exclude them from receiving a normal education, etc. The conflict in such group can lead to a complete inhibition of adult personality or to a halt in child development. Such conflicts are almost inevitable if the goals of the leader begin to diverge from the belief system that the ordinary members of the group had at the time of its creation;

b) it is possible to submit once to the set and proclaimed goals, norms and rules, actually elevated to dogma, the reproduction of one set of emotional preferences and expectations. The group becomes a kind of analogue of already established church, or club with very conservative rules, or company operating in a narrow sector (analogue of medieval workshops and artels). A natural way of genesis and further development of such groups is the departure of a real leader who determined the internal order and emotional background in the group. AI becomes an ideal conservation tool, reproducing the sum of the behavioral and emotional reactions of a departed leader. It can be argued that this is one of the most important boundary conditions for the identification of an individual and a small social group. With him, the adoption of such AI from outsiders is also possible as a factor in the spread of a new worldview, fashion, religion, new forms of family organization or activity. But the conflict between individuals within a group, or with the arising subgroup within the group, can relatively easily destroy conservative unity - because without a leader in the group, a new system of contradictions will develop;

c) AI work on maintaining the group integrity, as such, providing for the elimination of differences in pragmatic interests, emotional and behavioral reactions of group members, which is achieved by constant search and finding a certain common vector of development. This vector can change, bringing maximum advantage to all members of the group. An example here may be a company that requires a given percentage of profit, and exists as long as this profit goes to the salary of its employees. Areas of activity, preferences, and types of leisure are easily changed - just to prolong the existence of a group company. Here, the personal and group identity of individuals will be expressed not so much through belonging to a standard of behavior or the use of stable vocabulary, they are characterized by variability. But probably, 
through the constant awareness of the group members their interdependence and interconnection as a community of actors of large-scale joint activities. The boundary condition for identifying an individual with a small social group here is the speed of adaptation of the group as a whole, in comparison with the adaptability of an individual individual. If the idea of a partner disappears as an adequate continuation of oneself (because the «I» has adapted better), then the group, as a rule, breaks up.

AI can provide reformatting of the «I» of an individual or correction of his emotional preferences and expectations much better than teachers, traditional leaders of informal communities and sects, trade unions or firms by virtue of his constant communication with the individual, constant presence in his being. As a result, the individual will easily perform the usual labor operations, but learning ability will sharply decrease, there is a probability of occurrence of neuroses. Cases of serious neurotic and sometimes mental disorders are not ruled out.

Does this mean that AI will become a potentially dangerous technology for individuals? Rather, we can talk about the becoming of social contradiction at a new technological level.

On the one hand, AI designed to work with large social groups, or to ensure the normal functioning of government structures, will be relatively better than the cheap, low-powered AI used by small social groups. Therefore, they will be able to comprehensively influence individuals of small social groups. On the other hand, the widespread introduction of computers and the formation of the «Internet of things» contributes to the robotization of production and the reduction of the military and economic role of individuals. If in the heyday of the industrial era, the state was interested in a worker (employee, engineer, designer) and soldier, using totalitarian methods sought to compliance the conform of individuals by military-industrial standards, then in the near future, the need for human resources will not be so obvious.

Consequently, AI, as a tool for organizing a small social group, as a component of its polysubjectivity, possesses ambivalence. In the case of a utilitarian, narrowly functional use of AI, which does not lead to isolation of the individual from society, social groups receive an extremely useful and effective tool. In a small social group, an individual in many ways reveals his personal and/or professional opportunities, and exists in comfortable emotional conditions. Suppressing it will be counterproductive, which is confirmed by the modern problem of the atomization of society. But, if the impact of the AI -group on the individual becomes total, such intellect turns into an instrument of a kind of marginalization, self-isolation of a social group. 
If trace the history of small social groups, then almost always they need conditions, appropriate technical support. A family needs a house, a work team needs tools - forms change, but without material assets social groups do not exist. Similarly, the organizational and legal statuses of groups - there are customs and rituals of small communities, there is the legal status of clubs, families or cooperatives. In the short term, AI will become one of the tools providing a new level of development for such social groups, creating tangible assets and legal registration. Can talk, that AI will support the multisubjectivity and heterogeneous sociality of a small social group, providing choices in the activities of the group and directly influencing decisions. Moving away from the extremes of purely utilitarian cooperation and blind submission to the leader, AI can ensure the interaction of individuals in a group so as to maximize their personal or professional potential.

\section{SCIENTIFIC NOVELTY}

It is shown that AI will become a system-forming factor for the activities of small social groups of the future, which will increase the level of their subjectivity and sociality. In the absence of competitive confrontation, it will be possible to relatively quickly form new social groups, because the real contradictions of individuals will be smoothed out by a diverse virtual environment, individual in form, but unified in content. This will allow to start interaction, and then develop an activity strategy and a common style of behavior, emotional attachments and psychological attitudes of participants in social groups, which will solve the problem of personal identity at the individual group level. At the same time, an emotionally-cognitive retention of an individual in a similar group can become a fundamentally negative factor: in the event of an actual contradiction, the individual-group may suppress the individual's will, decrease his cognitive and behavioral capabilities, and activate unfavorable or negative emotional states. It is necessary to consider this factor, which contributes to the transformation of AI into an instrument of marginalization of small social groups. Therefore, it is possible that such small groups exist, where AI will take on the role of leader, forming an individual and group identity. Nonetheless, this negativity of the existence of social groups should not be absolutized. It will be substantially mitigated by the opposition of state institutions in the form of almost all large state structures - economic, political, legal, religious, ethnic, etc.

\section{CONCLUSION}

One of the problems of assessing the impact of new technologies, as a rule, involves a narrow range of forecasted situations and an incomplete list of those subjects that may be 
interested in their development. One of the varieties of collective subjects - small social groups - will continue to actively use AI. This will allow for flexible interaction between individuals, model their communication, relatively quickly create emotional attachments and a psychological background in the group, develop a common style of interaction, communication and activity, effectively form individual and group identities. Therefore, attempts to extrapolate the existing demographic or social trends of society and predict the development of small social groups without taking into account the AI factor can already be considered erroneous.

AI will be able to partially take on the role of organizer, intermediary, organizer of the communicative space in small social groups, perform diverse functions, stabilize situational communities and, ultimately, ensure the formation in those teams that are now considered unlikely. Many members of the group will identify the needs of AI as a continuation of their own, identify themselves with it cognitively and emotionally, planning their behavior and activities in general. And the boundary conditions for identifying an individual with a group, subject to a sufficient level of AI impact on the human psyche, can be set not only by rational, behavioral or emotional motives of group members, but also by the ratio of the capabilities of AI of a small social group and other AI (state, etc.). The universal boundary condition for the existence of a new type of social group will be the rate of change and adaptability of the behavior and activities of individuals as a whole, which AI can provide to meet the rapidly changing external conditions set by society. It is necessary to predict the development of small social groups now, because the speed of deployment of information technologies is higher than the speed, for example, of the spread of railways and the construction of highways.

As the closest historical perspective of the research, it is of interest to study the changing forms of personal identity in the context of the functioning of small social groups. It is also advisable to develop a categorical apparatus and mathematical models that will adequately describe the degree of isolation information flows in a small social group, which is a critical quantity for its functioning in self-isolation.

\section{REFERENCES}

1. Urry, J., 2018. Kak vygljadit budushhee? [What is the future?]. Publishing House «Delo» RANHiGS, Moscow. 320 p. (in Russian).

2. Demir, M., Cooke, N., \& Amazeen, P., 2018. A conceptual model of team dynamical behaviors and performance in human-autonomy teaming. Cognitive Systems Research, 52, 497-507. https://doi.org/10.1016/j.cogsys.2018.07.029

3. Artificial Intelligence for the Internet of Everything. Academic Press, 2019. 303 p. https://doi.org/10.1016/C2018-0-00012-2 
4. Artificial Intelligence in Society, 2019. OECD Publishing, Paris, 2019. 139 p. https://doi.org/10.1787/eedfee77-en

5. Marcus, G., 2014. What Comes After the Turing Test? New Yorker. Conde Nast, 9 June. Available at: < https://www.newyorker.com/tech/annals-of-technology/what-comesafter-the-turing-test >. Access: May 30. 2020.

6. Brooks, R., 2018. Steps Toward Super Intelligence IV, Thingsto Workon Now. RODNEY BROOKS Robots, AI, andotherstuff. RodneyBrooks., 15 July. Available at: $<$ https://rodneybrooks.com/forai-steps-toward-super-intelligence-iv-things-to-work-onnow/ >. Access: May 30. 2020.

7. Mavridis, N., 2015. A review of verbal and non-verbal human-robot interactive communication. Robotics and Autonomous Systems. Volume 63, Part 1. Pages 22-35 https://doi.org/10.1016/j.robot.2014.09.031

8. Hawking, S., 2019. Kratkie otvety na bol'shie voprosy [Brief Answers to the Big Questions]. Eksmo, Moscow. 256 p. (in Russian).

9. Nancy, J.L., 2004. Byitie edinichnoe mnozhestvennoe [Being Singular Plural]. Logvinov, Minsk. 272 p. (in Russian).

10. Nancy, J.L., 2009. Neproizvodimoe soobschestvo [Unproductive community]. Vodoley, Moscow. 208 p. (in Russian).

11. Kerimov, T.H., 2007. Nerazreshimosti [Insolubility]. Akademicheskiy Proekt; Triksta, Moscow. 218 p. (in Russian).

12. Sohova, Z.B., Redko, V.G., 2019. Modelirovanie poiska investitsionnyih resheniy avtonomnyimi agentami v prozrachnoy konkurentnoy ekonomike [Modeling the search for investment solutions by autonomous agents in a transparent competitive economy]. Iskusstvennyiy intellekt i prinyatie resheniy 2. p.98-108. https://doi.org/10.14357/20718594190210 (in Russian).

13. Bashlyar, G., 1987. Novyiy ratsionalizm [New rationalism]. Progress, Moscow. 376 p. (in Russian).

14. Van Dik, R., 2006. Predannost' i identifikacija v organizacii [Devotion and identification of the organization]. Gumanitarnyj centr, Kharkov. 142 p. (in Russian).

15. Bazarov, T.Yu., Kuzmina, M.Yu., 2005. Protsessyi sotsialnoy identichnosti v organizatsiyah [The processes of social identity in organizations]. Rossijskij psihologicheskij zhurnal 1. Pages 30-45. (in Russian)

16. Lerer, A., Peysakhovich, A., 2018. Maintaining cooperation in complex social dilemmas using deep reinforcement learning. Available at: < https://www.researchgate.net/publication/318206182_Maintaining_cooperation_in_compl ex_social_dilemmas_using_deep_reinforcement_learning >. Access: May 30. 2020.

17. Styopin, V.S., Kuznetsova, L.F., 1994. Nauchnaya kartina mira v kulture tehnogennoy tsivilizatsii [The scientific picture of the world in the culture of technogenic civilization]. IFRAN, Moscow. 274 p. (in Russian).

\section{ABOUT THE AUTHORS:}

\section{Vadym I. Palahuta}

$\mathrm{PhD}$ in Philosophy, Doctor of Philosophical science, Professor, National Metallurgical academy of Ukraine, Dnipro, Ukraine. E-mail: palaguta@ua.fm

(iD https://orcid.org/0000-0003-4254-1625 


\section{Stanislav S. Beskaravainyi}

$\mathrm{PhD}$ in Philosophy, Associate Professor, National Metallurgical Academy of Ukraine, Dnipro, Ukraine. E-mail: 2beskarss78@gmail.com

(iD https://orcid.org/0000-0003-1707-1369

Recebido em: 05 de junho de 2020 Aprovado em: 17 de novembro de 2020

Publicado em: 01 de fevereiro de 2021 